\title{
Impact of meal fatty acid composition on postprandial lipaemia, vascular function and blood pressure in postmenopausal women
}

Article

Accepted Version

Rathnayake, K., Weech, M., Jackson, K. and Lovegrove, J. (2018) Impact of meal fatty acid composition on postprandial lipaemia, vascular function and blood pressure in postmenopausal women. Nutrition Research Reviews, 31 (2). pp. 193-203. ISSN 0954-4224 doi:

https://doi.org/10.1017/S0954422418000033 Available at https://centaur.reading.ac.uk/75914/

It is advisable to refer to the publisher's version if you intend to cite from the work. See Guidance on citing.

To link to this article DOI: http://dx.doi.org/10.1017/S0954422418000033

Publisher: Cambridge University Press

All outputs in CentAUR are protected by Intellectual Property Rights law, including copyright law. Copyright and IPR is retained by the creators or other copyright holders. Terms and conditions for use of this material are defined in the End User Agreement. 


\section{www.reading.ac.uk/centaur}

\section{CentAUR}

Central Archive at the University of Reading

Reading's research outputs online 
Impact of meal fatty acid composition on postprandial lipaemia, vascular function and blood

4 Kumari M Rathnayake ${ }^{1,2}$, Michelle Weech ${ }^{1}$, Kim G Jackson $^{1}$ \& Julie A Lovegrove ${ }^{1}$

Wayamba University of Sri Lanka, Makandura, 60170, Sri Lanka

Disclaimer: There are no conflicts of interest.

KMR is supported by the Commonwealth Scholarship Commission, UK.

Corresponding Author: Julie A Lovegrove

Address correspondence to Prof JA Lovegrove, Hugh Sinclair Unit of Human Nutrition, Department of Food \& Nutritional Sciences, University of Reading, Reading, RG6 6AP, United Kingdom. Telephone: +44 (0)118 3786418; Fax: +44 (0)118 3787708; Email: j.a.lovegrove@reading.ac.uk.

Running title: Meal fat, lipaemia and vascular function

\section{Abbreviations in the text}

ACE: angiotensin-converting enzyme; Apo: apolipoprotein; AUC: area under the curve; BMI: body mass index; CETP: cholesteryl ester transfer protein; CM: chylomicron; CMR: CM remnants; CVD: cardiovascular disease; FMD: flow-mediated dilatation; HDL: high density lipoprotein; HDL-C: HDL cholesterol; LDL: low density lipoprotein; LDL-C: LDL cholesterol; LPL: lipoprotein lipase; MUFA: monounsaturated fatty acid; NEFA: non-esterified fatty acids; NO: nitric oxide; PUFA: polyunsaturated fatty acid; RAS: renin-angiotensin system; RCT: randomised clinical trial; RE: Retinyl esters; ROS; reactive oxygen species; Sf: Svedberg flotation rate; SFA: saturated fatty acid; TAG: triacylglycerol; TC: total cholesterol; TRL: TAG-rich lipoprotein; VLDL: very low density lipoprotein. 
Abstract

Cardiovascular diseases (CVD) are the leading cause of death in women globally, with aging associated with progressive endothelial dysfunction and increased CVD risk. Natural menopause is characterised by raised non-fasting triacylglycerol (TAG) concentrations and impairment of vascular function compared with premenopausal women. However, the mechanisms underlying the increase in CVD risk after women have transitioned through the menopause are unclear. Dietary fat is an important modifiable risk factor in relation to both postprandial lipaemia and vascular reactivity. Meals rich in saturated and monounsaturated fatty acids are often associated with greater postprandial TAG responses compared with those containing n-6 polyunsaturated fatty acids, but studies comparing the effects of these fatty acids on vascular function during the postprandial phase are limited, particularly in postmenopausal women. A systematic search of the literature identified 778 publications describing acute postprandial test meal studies including postmenopausal women. The impact of fat-rich meals on postprandial lipaemia was reported in 7 relevant studies, of which meal fat composition was compared in one study described by three papers. An additional study determined the impact of a high fat meal on vascular reactivity. Although there is moderately consistent evidence to suggest detrimental effects of high fat meals on postprandial lipaemia in postmenopausal women (compared with premenopausal women), there is insufficient evidence to establish the impact of meals of differing fat composition. Furthermore, there is no robust evidence to conclude the impact of meal fatty acids on vascular function or blood pressure. In conclusion, there is an urgent requirement for suitably powered robust randomised controlled trials to investigate the impact of meal fat composition on postprandial novel and established CVD risk markers in postmenopausal women, an understudied population at increased cardiometabolic risk.

\section{Introduction}

Cardiovascular diseases (CVD) which include coronary heart disease (myocardial infarction and angina), stroke and peripheral vascular disease ${ }^{(1)}$ are a key contributor to the burden of disease globally ${ }^{(2)}$. Over the past 50 years, the prevalence of CVD has fallen in Western populations, however, CVD are currently the major cause of death in women in the UK, accounting for $32 \%$ of all deaths ${ }^{(3)}$. Furthermore, the prevalence of CVD is dramatically increasing in other areas, including Eastern Europe, Asia and the Indian subcontinent ${ }^{(4)}$.

The aetiology for CVD is multifactorial and includes several modifiable risk factors, such as cigarette smoking, a sedentary lifestyle, obesity, elevated blood pressure, dyslipidaemia, type 2 diabetes mellitus, and non-modifiable factors, such as advancing ageing, sex, family history of heart disease and ethnicity ${ }^{(5 ; 6)}$. Among the non-modifiable risk factors, ageing is associated with 
progressive endothelial dysfunction (characterised by a loss of vascular wall homeostasis leading to a decrease in vascular reactivity and raised blood pressure) in both sexes, although it appears to occur earlier in men than women ${ }^{(7)}$. The most prominent sex related difference in physiological ageing is the menopause (cessation of menstruation) in women, which usually occurs between the ages of 45 and $55 \mathrm{y}$, with $51 \mathrm{y}$ being the average age of menopause in the UK ${ }^{(8)}$. This natural part of aging in women contributes a significant cardiovascular milestone in terms of both physiology and pathology since oestrogen deficiency is known to impair lipid metabolism and endothelial function, and the menopause is a recognised risk factor for $\mathrm{CVD}^{\left({ }^{(9)}\right.}$. It has further been shown by Schouw et al. ${ }^{(10)}$ that for each year of delay in the age of onset of the natural menopause, CVD risk falls by $2 \%$.

\section{Postprandial lipaemia}

Kolovou et al. defined postprandial lipaemia as a complex syndrome characterised by non-fasting hypertriacylglycerolaemia and its augmentation is associated with increased risk of cardiovascular events ${ }^{(11)}$. Following a fat containing meal, there is a transient rise in circulating triacylglycerol (TAG) rich lipoproteins (TRL), such as chylomicrons (CM) and very low density lipoprotein (VLDL). After entering the circulation, the CM TAG is hydrolysed into non-esterified fatty acids (NEFA) by lipoprotein lipase (LPL) forming cholesterol ester rich CM remnants, which are cleared by the liver by receptor-mediated uptake. VLDL follows a similar route of metabolism in the circulation as CM particles, but VLDL are hydrolysed at a slower rate, as the larger CM are preferential substrate for LPL. VLDL TAG depletion produce smaller VLDL (intermediate density lipoprotein or VLDL remnants), ultimately a proportion of which will be metabolised to low density lipoprotein (LDL). LDL particles are cleared from the bloodstream via the hepatic LDL receptor using apoB-100 as a ligand. During the postprandial period, there is an accumulation of TRL in the circulation due to competition between intestinal and hepatic TRL for the same lipolytic and receptor mediated uptake ${ }^{(12)}$. A delayed clearance of TRLs in the circulation enhances the accumulation of TRL particles carrying acceptor sites for the cholesteryl ester transfer protein (CETP) which transfers TAG from TRLs (CM and VLDL) and exchanges it with cholesteryl esters from high density lipoprotein (HDL) and LDL. Remodelling of the lipid content of the LDL and HDL particles make them suitable substrates for LPL and hepatic lipase, leading to the formation of smaller denser $\mathrm{LDL}\left(\mathrm{LDL}_{3}\right)$ and $\mathrm{HDL}\left(\mathrm{HDL}_{3}\right)$ particles ${ }^{(13)}$. $\mathrm{HDL}_{3}$ is rapidly removed from the circulation decreasing circulating HDL cholesterol (HDL-C) concentrations, which is one proposed mechanism for the inverse association between exaggerated postprandial lipaemia and CVD risk (14). Another possible mechanism is that $\mathrm{LDL}_{3}$ has a lower binding affinity to the LDL-receptor, 
reducing their rate of clearance from the circulation and enabling them to infiltrate the arterial wall (13)

Since atherosclerosis is now also considered to be a postprandial phenomenon, three large prospective cohort studies aimed to determine the link between cardiovascular events and nonfasting TAG ${ }^{(15 ; 16 ; 17)}$. In the Norwegian Counties Study, hazard ratios of 1.2 and 1.03 for deaths from CVD per $1 \mathrm{mmol} / \mathrm{l}$ increase in non-fasting TAG were reported in women and men, respectively, after 27 years of follow up in a total of 86,261 participants ${ }^{(17)}$. Furthermore, the Copenhagen City Heart Study that followed 7581 women and 6391 men for 31 years showed that relative to women with non-fasting TAG of $<1 \mathrm{mmol} / \mathrm{L}$, hazard ratios for myocardial infarction ranged from 1.5 for women with TAG between 1.0-1.99 mmol/L rising to 4.2 for those with TAG $\geq 5 \mathrm{mmol} / \mathrm{L}^{(16)}$. However, the corresponding hazard ratios for men were 1.3 and 2.1 , respectively. In the Women's Health Study, fasting $(n=20,118)$ and non-fasting $(n=6391)$ TAG predicted cardiovascular events after 11.4 years of follow up after adjusting for age, blood pressure, smoking status and hormone therapy. The authors also reported that the strongest association between cardiovascular events and non-fasting TAG occurred 2-4 $\mathrm{h}$ after the last meal, with the association declining as the fasting time increased ${ }^{(15)}$. These studies have demonstrated the greater importance of non-fasting than fasting TAG concentrations as a predictor of CVD risk in women than men.

The relationship between postprandial lipaemia and CVD according to menopausal status is a topic of current interest. The impact of menopausal status on the variability of the postprandial lipaemic responses have been reported in a number of studies ${ }^{(18 ; 19 ; 20 ; 21)}$ (Supplemental material 1). In general, premenopausal women have lower postprandial triacylglycerol (TAG) responses than men ${ }^{(22 ; 23 ; 24 ; 25)}$, which is in contrast to the higher reported responses observed in postmenopausal women compared with men of a similar age ${ }^{(26)}$. In response to a single oral vitamin A fat loading test, van Beek et al. ${ }^{(18)}$ investigated whether a natural menopause was associated with reduced protection from exaggerated postprandial lipaemia. Higher concentrations of postprandial plasma TAG and retinyl palmitate (an indirect marker of CM) were observed in postmenopausal women compared with premenopausal women of similar age, BMI, daily energy and fat intake, APOE genotype, LPL activity, and HDL-C concentration, even after adjusting for the confounding effect of fasting TAG. Relative to premenopausal women, Masding et al. ${ }^{(20)}$, Schoppen et al. ${ }^{(19)}$ and Jackson et $_{\text {al. }}{ }^{(21)}$ also reported significantly higher postprandial TAG responses after single and sequential fat-rich test meals in healthy postmenopausal women. Although raised LDL cholesterol (LDL-C) is an established risk factor for CVD, large prospective studies have shown non-fasting TAG to be a better predictor of CVD risk in women than fasting LDL-C ${ }^{(27 ; 28 ; 29)}$. Post-hoc analysis of the The Dietary Studies: Reading Unilever Postprandial Trials (DISRUPT) menopausal groups according to age also revealed a greater increase in non-fasting TAG than fasting LDL-C during the 
late premenopausal period suggesting that age and the menopause have a differential impact on these two lipid CVD risk biomarkers ${ }^{(21)}$.

A major biochemical change that occurs in women after the menopause is a reduction in the secretion of endogenous oestrogen and progesterone ${ }^{(30)}$. These hormones not only play a major role in sexual physiology, but are also involved in various physiological processes associated with the vasculature and lipid metabolism. A reduction in oestrogen following the menopause has been shown to have a detrimental impact on lipoprotein metabolism, vascular reactivity and blood pressure (Figure 1). For example, there is much evidence to suggest that oestrogen (endogenous and exogenous) lowers fasting plasma concentrations of total and LDL-C, lipoprotein (a) and apolipoprotein B, whilst elevating HDL-C and apolipoproteins AI and AII ${ }^{(31 ; 32 ; 33)}$. The impact of oestradiol (the predominant type of oestrogen) on lipid metabolism is reported to contribute $25 \%$ of its protective effects for fasting lipid profile ${ }^{(34)}$. One possible mechanism to explain this effect, that was identified in in vitro animal studies, was an increase in the number of high affinity LDL receptors on liver cell membranes that enhance LDL uptake by the liver ${ }^{(33)}$. Exaggerated postprandial lipaemia is observed after the menopause ${ }^{(18)}$ but the administration of even short term (two to six weeks) oestradiol therapy reduces the menopause-related rise in postprandial TAG in postmenopausal women $^{(35 ; 36)}$. These findings indicate that $17 \beta$-estradiol may accelerate the postprandial clearance of TRL and have a beneficial effect on postprandial lipaemia.

\section{Vascular function and blood pressure}

Vascular function is a measure of cardiovascular health. The components of impaired vascular function, including hypertension ${ }^{(37 ; 38)}$, arterial stiffness ${ }^{(39)}$ and impaired endothelial dependent vasodilation (endothelial dysfunction) ${ }^{(40 ; 41)}$, are all associated with cardiovascular mortality. In a healthy blood vessel, the endothelium, which is comprised of a monolayer of endothelial cells that lines the blood vessel walls, regulates vascular wall homeostasis by immediately responding to blood-borne and locally produced stimuli to regulate blood flow, blood pressure and vascular tone. It does so by maintaining a precise balance between the release of endothelium-derived vasodilators (such as nitric oxide (NO)), and vasoconstrictors (such as endothelin-I), which actively regulates vascular permeability to plasma constituents, platelets and leukocyte adhesion molecules ${ }^{(42)}$ as well as aggregation and thrombosis ${ }^{(43)}$. However, when the production or bioavailability of NO is reduced, the resulting imbalance of these vasoactive substances disrupts vascular homeostasis. This 'endothelial dysfunction' is characterised by vasoconstriction, increased expression of adhesion molecules and pro-inflammatory cytokines, platelet activation and increased oxidative stress ${ }^{(44)}$, and is becoming increasingly recognised as an important step for the initiation of coronary atherosclerosis ${ }^{(45)}$ and CVD risk in postmenopausal women ${ }^{(46)}$. There is supporting evidence of 
impaired endothelial function after the menopause, which has been associated with a lack of endogenous oestrogen ${ }^{(7 ; 47)}$.

There are a number of non-invasive methods which are used to evaluate endothelial function (48). Flow-mediated dilatation (FMD) is the gold standard technique that uses ultrasound to assess endothelium-dependent vasodilation in the conduit arteries in the peripheral circulation and is used as a surrogate measure of NO production ${ }^{(49)}$. It is now recognised as a screening tool to assess future CVD risk ${ }^{(40 ; 46 ; 50 ; 51)}$. Rossi et al. reported that postmenopausal women in the lowest tertile of $\%$ FMD response (reflective of impaired vascular reactivity) had the greatest relative risk of cardiovascular events. Furthermore, it has been shown that endothelial function is impaired across the stages of the menopause transition in healthy women with the highest \% FMD response reported in premenopausal women, with a progressive decline in perimenopausal and postmenopausal women, respectively ${ }^{(52)}$. This suggests the perimenopausal stage (the transition towards the menopause where oestrogen production starts to fall) is a crucial turning point in women where changes in CVD risk commence.

Majmudar et al. ${ }^{(53)}$ revealed that menopausal status is associated with reduced NO activity, which is restored with oestrogen replacement therapy and may be an important mechanism facilitating the detrimental effect of the menopause on CVD risk and mortality. Another study that acutely administered oestrogen (17 $\beta$-oestradiol) to postmenopausal women demonstrated protective effects on forearm microvascular responses to both endothelium-dependent (acetylcholine) and independent vasodilation (sodium nitroprusside) via improvements in NO activity ${ }^{(54)}$. Impaired blood flow in the microcirculation has been proposed to be an indicator of initial endothelial damage in subjects at risk of CVD ${ }^{(55)}$. Furthermore, it has been repeatedly shown that $17 \beta$ oestradiol stimulates the production of vasodilatory prostaglandins, such as prostacyclin $\left(\mathrm{PGI}_{2}\right){ }^{(56 \text {; }}$ 57). These vascular effects are believed to be partly responsible for the long-term benefit of oestrogen therapy on cardiovascular risk in postmenopausal women. However, findings from the Women's Health Initiative study have questioned the benefits of oestrogen therapy, reporting that oestrogen therapy did not protect against myocardial infarction or coronary death after a short (6.8 y) or longer-term (18 y) follow-up relative to a placebo, although the findings did show a lower risk of coronary heart disease among the younger postmenopausal women (50 to $59 \mathrm{y})^{(58 ; 59)}{ }^{(59)}$. More recently, a systematic review involving 43,637 women reported the number of cardiovascular events to increase following the long-term (>1 y) use of oestrogen therapy ${ }^{(60)}$. In contrast, there is much evidence to suggest that oestrogens (endogenous and exogenous) have several cardioprotective effects (Figure 1) ${ }^{(32 ; 61 ; 62)}$. These include reductions in plasma markers of endothelial activation (E-selectin) and increased fibrinolytic activity (increased factor VII; reduced fibrinogen, 
plasminogen activator inhibitor type 1 and tissue plasminogen activator) ${ }^{(32 ; 63)}$. However, increased markers of inflammation (C-reactive protein) and hypercoagulability have also been reported ${ }^{(32 ; 61)}$. Hypertension (high blood pressure) is one of the main age-related disorders in postmenopausal women ${ }^{(64 ; 65)}$, which has been identified as a leading risk factor for myocardial infarction and stroke in women ${ }^{(66)}$. The renin-angiotensin system (RAS) is a hormonal cascade, which plays a key role in the regulation of fluid and electrolyte balance, and arterial blood pressure. Upon activation of the RAS cascade, angiotensin II is produced in the liver by angiotensinconverting enzyme (ACE) following conversion of angiotensin I to angiotensin II ${ }^{(67)}$. Angiotensin II is a potent vasoconstrictor which degrades bradykinin (a vasodilator) causing arterioles to constrict, resulting in increased blood pressure ${ }^{(68)}$. It is well documented in the literature that oestrogen acts on RAS at different points of the cascade including the inhibition of ACE activity. In vitro and in vivo animal studies have also demonstrated the potential effects of oestrogen on the endothelial-dependent vasodilator response to acetylcholine due to oestrogen induced sensitisation measured in coronary and uterine arteries ${ }^{(69 ; 70 ; 71)}$. Loss of oestrogen-dependent cardiovascular protection induces endothelial dysfunction, and may also be involved in the activation of the RAS cascade. Evidence from both clinical and animal studies have shown an inverse association between oestrogen and the activation of RAS ${ }^{(72 ; 73 ; 74 ; 75)}$. This has been proposed to occur due to oestrogen induced downregulation of angiotensin receptor I expression leading to an augmented level of angiotensin II ${ }^{(73)}$ (which is a major component of the RAS system) and has several harmful effects on the vascular wall including vasoconstriction, vascular smooth muscle cell proliferation, reactive oxygen species (ROS) generation, and endothelial cell apoptosis ${ }^{(76 ; 77 ; 78)}$. Oestrogen deficiency has also been reported to lead to an upregulation of ACE activity causing an accumulation of angiotensin II $^{(79)}$.

\section{Impact of meal fat composition on postprandial lipaemia and vascular function}

Diet is one of the most important modifiable risk factors in relation to CVD ${ }^{(80)}$. As a strategy to reduce the incidence of CVD, public health policy makers recommend that intakes of dietary saturated fatty acids (SFA) are reduced to $<10 \%$ total energy in the UK ${ }^{(81)}$. Substituting SFA with unsaturated fatty acids may provide additional benefits in relation to CVD risk factors, including reductions in the fasting lipid profile and improvements in endothelial function. A systematic review proposed that lowering dietary SFA intake by modifying dietary fat composition rather than reduction in total fat intake, may reduce cardiovascular events by $14 \%{ }^{(82)}$. Since individuals spend a large proportion of the day in the fed (postprandial) state, modifications to the fatty acid composition of our meals that are repeated on a daily basis may have a significant impact on postprandial lipaemia and vascular health, which over time could affect CVD risk. 
The chronic effects of substitution of SFA with polyunsaturated fat (PUFA) on fasting lipid 244 levels have been extensively studied ${ }^{(83)}$, however, the acute affects are less well known. One 245 systematic review and meta-analysis of RCT compared the effects of oral fat tolerance tests with differing fatty acid compositions on postprandial TAG responses in men and women ${ }^{(84)}$. Relative to a single SFA-rich meal challenge, a PUFA-rich meal significantly reduced the postprandial lipaemic response over $8 \mathrm{~h}$, whereas a trend for a reduced response was identified following a monounsaturated (MUFA) rich meal challenge. However, differences were not evident at $4 \mathrm{~h}$ suggesting that a longer follow-up time after the test meal (i.e. $8 \mathrm{~h}$ ) is required to observe the acute effects of meal fat composition on postprandial lipaemia. Of the 18 studies included in the review by Monfort-Pires et al. ${ }^{(84)}$ none of the studies included postmenopausal women which reflects the paucity of postprandial data in this population subgroup.

With regards to vascular function, West and colleagues ${ }^{(85)}$ reported that consumption of a single high fat meal (50-105 g of fat) can impair postprandial FMD by $45 \%$ to $80 \%$ with observations of impaired FMD within 2 to $5 \mathrm{~h}$ after a high fat meal ${ }^{(86 ; 87 ; 88 ; 89)}$. Prolonged postprandial lipaemia is known to induce endothelial dysfunction by promoting the formation of free radicals by accelerating the rate of $\beta$-oxidation of free fatty acids (e.g. superoxide radicals). Increased production of ROS or free radicals reduce the amount of bioactive NO by chemical inactivation to form toxic peroxynitrite ${ }^{(90)}$. In addition, it has been shown that persisting oxidative stress will render endothelial nitric oxide synthase dysfunctional, markedly reducing NO production (91). Indeed, high concentrations of TRLs during the postprandial state enhance inflammation by inducing the secretion of pro-inflammatory cytokines ${ }^{(92)}$ and expression of soluble cell adhesion molecules ${ }^{(93)}$.

Reviews by Hall ${ }^{(94)}$ and Vafeiadou et al. ${ }^{\left({ }^{95}\right)}$ stated that the acute effects of dietary fats on vascular function is less researched. The authors concluded that high fat meals have a detrimental effect on postprandial vascular function and that there is limited and inconclusive evidence for the comparative effects of test meals rich in MUFA or n-6 PUFA with SFA. Of note, the data derived from these reviews were mainly from studies where the effects of a single high fat meal on postprandial vascular function in different subject groups were determined; however, none of the studies identified in these reviews included only postmenopausal women only.

Therefore, we aimed to systematically review and critically evaluate the existing evidence from acute studies comparing meals rich in SFA, MUFA and n-6 PUFA on postprandial lipaemia, vascular reactivity, blood pressure and biomarkers of vascular function and inflammation in postmenopausal women. It is very timely to focus on postmenopausal women since they represent an understudied group within the population at increased CVD risk. 


\section{Subjects and methods}

279 A systematic approach was used to identify all relevant published literature according to the method 280 used by Vafeiadou et al. ${ }^{(95)}$. The PubMed (http://www.ncbi. nlm.nih.gov/pubmed/) database was 281 used to perform the literature search, which included all studies published in English until October 2016. A protocol that included search terms to conduct the literature search was prepared by two authors (KMR and MW) and then agreed by all authors. Three categories of search terms were identified: i) study group search term (postmenopausal or post-menopausal or post menopause or menopause or menopausal); ii) exposure search terms (which included descriptors of SFA, MUFA and n-6 PUFA, and relevant food sources, e.g. butter, safflower oil and olive oil); iii) outcomes (which included descriptors of vascular function, blood pressure, biomarkers of vascular function and inflammation, and plasma lipids) (Supplementary Information). The Medical Subject Heading Browser (http://www.nlm.nih.gov/mesh/MBrowser.html) was used to identify relevant exposures and outcomes. Additional studies $(n=2)$ were identified through hand searching of original articles found using the PubMed search. The titles and abstracts of every paper was assessed for relevance at the initial stage by one author (KMR) and any uncertainties were discussed with other members of the review team until a consensus was reached. This review was restricted to epidemiological studies (cross-sectional, case-control and cohort) and RCT in postmenopausal women with respect to test meals rich in SFA, MUFA and/or n-6 PUFA. Only published peer-reviewed literature was considered (i.e. 'grey' literature, such as dissertations, conference proceedings, reports, letters to editors and other non-peer-reviewed research were excluded). Although Hall ${ }^{(94)}$ and Vafeiadou et $a l .{ }^{(95)}$ previously reviewed the chronic and acute studies on vascular function, they did not specifically address the acute effects in postmenopausal women. In this present review, we only considered acute studies as our objectives were to determine the impact of meal fatty acids on nonfasting TAG responses, vascular function and blood pressure as important CVD risk factor in postmenopausal women. Figure 2 presents a summary of the literature search and reasons for exclusion of the studies.

\section{Results and Discussion}

This systematic search identified 778 publications in total. Of these, there were nine relevant articles describing seven independent studies in postmenopausal women that examined the acute effects of meals enriched in SFA and/or MUFA and/or n-6 PUFA on postprandial lipaemia ${ }^{(96 ; 97 ; 98 ;}$ $99 ; 100 ; 101 ; 102 ; 103 ; 104)$. One of these studies also determined the impact of a single fat containing meal with a low PUFA:SFA ratio on vascular function ${ }^{(101)}$ (Table 1). No studies were identified that reported the acute impact of meal fatty acids on postprandial blood pressure, or biomarkers of vascular function and inflammation in postmenopausal women. Only one single-blind RCT 
compared the effects of meal fat composition on postprandial lipaemia using a sequential meal protocol, the results of which were presented in three publications ${ }^{(97 ; 98 ; 100)}$. As opposed to a single meal protocol, the use of a multiple meal design by the researchers is considered superior because it more closely mimics the eating pattern of free-living individuals, particularly in Westernised societies, and provokes a sustained lipaemic response. Five publications described cross-sectional epidemiological studies, which were single arm studies that did not have comparator meals and whose fatty acid compositions varied ${ }^{(96 ; 101 ; 102 ; 103 ; 104)}$. Among these postprandial studies with blood samples collected between 6 to 10 hours after the test meal, two studies ${ }^{(96 ; 102)}$ used a sequential two meal protocol, whereas the other three studies ${ }^{(101 ; 103 ; 104)}$ incorporated a single meal approach. In addition, one case-control study was identified that considered the responses of normolipaemic, hypercholesterolaemic and mixed hyperlipidaemic postmenopausal women to a single high fat meal ${ }^{(99)}$.

Data on these human studies will be presented in two sections that address the effects of total fat or fatty acid composition on i) postprandial lipaemia and ii) postprandial vascular function in postmenopausal women.

\section{Acute effects of meal fat composition on postprandial lipaemia}

The five cross-sectional studies, investigating both single and sequential meals, provided consistent evidence that fat-rich loads, irrespective of fatty acid composition, augment postprandial lipaemia in postmenopausal women, with an increase in TAG being observed in all five studies during the postprandial period relative to baseline ${ }^{(96 ; 101 ; 102 ; 103 ; 104)}$ (Table 1). Furthermore, Pirro et al. ${ }^{(99)}$ investigated the changes in postprandial TAG concentrations after a standardised oral fat load $(65 \mathrm{~g}$ of fat) at baseline, 4, 6 and $8 \mathrm{~h}$ in postmenopausal women with hypercholesterolemia and mixed hyperlipidaemia and compared them with a control group of normolipidaemic postmenopausal women. A significantly greater postprandial TAG response was found in the mixed hyperlipidaemic women than in the hypercholesterolaemic and normolipidaemic women which may reflect their higher baseline TAG concentrations. As expected, other factors involved in lipid metabolism, including increases in apo B-48 ${ }^{(102)}$, glucose ${ }^{(103)}$, and insulin ${ }^{(103)}$ as well as reductions in HDL ${ }^{(99}$; 103; 104), glutathione ${ }^{(101)}$ and NEFA ${ }^{(103)}$ were also observed postprandially compared with fasting values. However, comparison of the findings from the different studies are challenging due to differences in the nature of the fats and oils used in the test meal, the amount and composition of fat, and postprandial follow up times, as well as the use of both single and sequential test meal protocols. They are also limited in their cross-sectional design in that the lack of comparator meals prevents any conclusions from being made regarding the impact of meal fat composition on postprandial lipaemia. Among all nine articles (seven independent studies) reported in Table 1, only 
one study that was described in three publications compared the postprandial lipaemic responses to test meals containing oils rich in SFA (palm oil), MUFA (olive oil), n-6 PUFA (safflower oil) and a mixture of n-6 PUFA and n-3 PUFA (safflower and fish oils) ${ }^{(97 ; 98 ; 100)}$. In this study, 10 postmenopausal women ingested a high fat breakfast containing $40 \mathrm{~g}$ of the assigned test fat followed by a low fat, high carbohydrate lunch ( $5.4 \mathrm{~g}$ total fat) given $5 \mathrm{~h}$ later. The authors observed significantly higher levels of plasma NEFA and lower insulin sensitivity following the SFA meal compared with the other test oils. During the postprandial state it has been shown that up to $50 \%$ of the liberated NEFA is dietary-derived CM-TAG due to the action of LPL upon TAG to release NEFA ${ }^{(100)}$. Although Robertson et al. ${ }^{(100)}$ did not determine the specific fatty acid composition of the circulating NEFA after consumption of the meals, a similar study reported the postprandial change in the plasma NEFA profile to represent the fatty acid composition of the test meals ${ }^{(105)}$. Based on the same sequential meal study, Jackson et al. further examined the postprandial TAG and apo B-48 (the apolipoprotein specifically associated with CM) responses, including the responses in three distinct TRL subfractions, and reported significant differences in the apo B-48 time course profiles between the four different test oils ${ }^{(98)}$. In particular, the MUFA meal resulted in the formation of a greater number of both large (Svedberg flotation rate $\left(\mathrm{S}_{\mathrm{f}}>400\right.$ fraction) and moderately $\left(\mathrm{S}_{\mathrm{f}} 60-400\right.$ fraction) sized apo B-48 particles compared with the other three study meals. The findings from this study suggested that olive oil may enhance CM formation and Jackson et al. ${ }^{(97)}$ hypothesised that MUFA may modify the activity or expression of intestinal microsomal TAG transfer protein, which is involved with TRL lipoprotein assembly.

\section{Acute effects of meal fat composition on vascular function}

Only one study has also examined the acute impact of total fat and/or SFA and/or MUFA and/or n-6 PUFA on vascular reactivity in postmenopausal women. A significant decrease in the \%FMD response at $2 \mathrm{~h}(2.3 \pm 2.6 \%)$ compared with baseline $(7.7 \pm 2.8 \%, \mathrm{p}<0.05)$ was observed in healthy postmenopausal women after a $65 \mathrm{~g}$ oral fat load with a PUFA:SFA ratio of $0.06^{(101)}$ (Table 1). Since a comparator meal of a different fatty acid composition was not included in this study, conclusions regarding the impact of fatty acid composition on vascular function in postmenopausal women cannot be determined.

\section{Summary}

A systematic approach was used to review the literature on the impact of meal fat composition (SFA, MUFA and n-6 PUFA) on postprandial lipaemia, blood pressure, vascular function and biomarkers of vascular function and inflammation in postmenopausal women. However, there is at present, an extremely limited number of RCT that have investigated the impact of meal fatty acid 
composition on measures of postprandial lipaemia and vascular function in this population subgroup. Furthermore, differences in study designs (such as the absence of a comparator test meal, and differences in meal fat composition, study duration and outcome measures) prevent any firm conclusions being drawn from this literature review.

\section{Conclusions}

In conclusion, there is an urgent requirement for suitably powered RCT to investigate the effects of meal fat composition on postprandial lipaemia and vascular function in postmenopausal women. With the increased prevalence of non-communicable diseases in women, especially after the menopause, future studies should consider both healthy postmenopausal women and those at increased cardiometabolic risk using well-standardised measures of vascular function. Since nonfasting TAG is an important CVD risk factor for women, it is essential to use robust test meal protocols that are more reflective of habitual eating patterns to gain a greater understanding of the day-long postprandial handling of different dietary fats.

\section{Acknowledgements}

The authors' responsibilities were as follows: KMR, MW, KGJ and JAL contributed to the conception of the literature search strategy. KMR undertook the literature search, extracted and interpreted the data from the literature and wrote the manuscript. MW, KGJ and JAL critically appraised the document at all stages. KGJ and JAL critically appraised the final manuscript. JAL was responsible for the final content. None of the authors have any conflicts of interest.

\section{Financial support}

KMR was supported by the Commonwealth Scholarship Commission, UK. This research received no specific grant from any funding agency, commercial or non-profit sectors. 
Table 1 Acute test meal studies investigating the effects of meal fat content and composition on postprandial lipaemia and vascular function in postmenopausal women

\begin{tabular}{|c|c|c|c|c|c|c|c|c|}
\hline Reference & $\begin{array}{l}\text { Subject group, } \\
\text { age (mean) and n }\end{array}$ & $\begin{array}{l}\text { Study } \\
\text { design }\end{array}$ & $\begin{array}{l}\text { Meal } \\
\text { type }\end{array}$ & $\begin{array}{l}\text { Amount of } \\
\text { fat }(\% \text { meal } \\
\text { fat if } \\
\text { available) } \\
\end{array}$ & Fatty acid composition & $\begin{array}{l}\text { Time of } \\
\text { postprandial } \\
\text { data }\end{array}$ & $\begin{array}{l}\text { Postprandial } \\
\text { measurements } \\
\text { (plasma/serum) }\end{array}$ & $\begin{array}{l}\text { Significant outcomes compared to } \\
\text { baseline, unless otherwise stated }\end{array}$ \\
\hline \multicolumn{9}{|c|}{ Postprandial lipaemia } \\
\hline $\begin{array}{l}\text { Westerveld et } \\
\text { al. }(1996)^{(104)}\end{array}$ & $\begin{array}{l}59 \text { y n } 16 \\
\text { normolipidaemic }\end{array}$ & $\begin{array}{l}\text { Cross } \\
\text { sectional }^{*}\end{array}$ & Single & $50 \mathrm{~g}(40 \%)$ & PUFA: SFA 0.06 & $8 \mathrm{~h}$ & $\begin{array}{l}\text { TAG, HDL-C } \\
\text { and HDL-Apo } \\
\text { A-1 }\end{array}$ & $\begin{array}{l}\downarrow \mathrm{HDL}-\mathrm{C} \text { at } 3 \text { to } 8 \mathrm{~h}(\mathrm{p}<0.05), \\
\downarrow \mathrm{HDL}-\mathrm{Apo} \mathrm{A}-1 \text { at } 3 \text { and } 6 \mathrm{~h}(\mathrm{p}<0.05) \\
\uparrow \mathrm{TAG} \text { at } 8 \mathrm{~h}(\mathrm{p}<0.05)\end{array}$ \\
\hline $\begin{array}{l}\text { Pirro et al. } \\
(2001)^{(99)}\end{array}$ & $\begin{array}{l}57 \text { y n } 17 \\
\text { normolipaemic, } \\
54 \text { y } 17 \\
\text { hypercholesterola } \\
\text { emia and } 55 \text { y n } \\
16 \text { mixed } \\
\text { hyperlipaemia }\end{array}$ & $\begin{array}{l}\text { Case } \\
\text { control }\end{array}$ & Single & $65 \mathrm{~g}(83 \%)$ & PUFA: SFA 0.06 & $8 \mathrm{~h}$ & $\begin{array}{l}\text { TC, TAG, } \\
\text { HDL-C, HDL }_{2} \\
\mathrm{HDL}_{3}, \mathrm{LDL}, \\
\text { LDL particle } \\
\text { size, and Lp(a) }\end{array}$ & $\begin{array}{l}\uparrow \mathrm{TAG} \text { at } 4,6 \text { and } 8 \mathrm{~h}, \downarrow \mathrm{HDL}-\mathrm{C} \text { at } 6 \mathrm{~h} \\
\text { and } \downarrow \mathrm{Lp}(\mathrm{a}) \text { at } 4 \text { and } 6 \mathrm{~h} \text { in } \\
\text { normolipaemic PoM }(\mathrm{p}<0.05) \\
\uparrow \mathrm{TAG} \text { at } 4,6 \text { and } 8 \mathrm{~h}, \downarrow \mathrm{HDL}-\mathrm{C} \text { at } 4 \\
\text { and } 6 \mathrm{~h}, \downarrow \mathrm{HDL}_{2} \text { at } 4 \mathrm{~h} \text { and } \downarrow \mathrm{Lp}(\mathrm{a}) \text { at } 4 \\
\mathrm{~h} \text { in hypercholesterolaemia PoM } \\
(\mathrm{p}<0.05)\end{array}$ \\
\hline & & & & & & & & $\begin{array}{l}\uparrow \mathrm{TAG} \text { at } 4,6 \text { and } 8 \mathrm{~h}, \downarrow \text { LDL size at } 4 \\
\text { and } 6 \mathrm{~h}, \downarrow \mathrm{HDL}-\mathrm{C} \text { at } 4,6 \text { and } 8 \mathrm{~h} \text {, } \\
\downarrow \mathrm{HDL} 2 \text { at } 6 \mathrm{~h} \text { and } \downarrow \mathrm{Lp}(\mathrm{a}) \text { at } 4 \text { and } 6 \mathrm{~h} \\
\text { in mixed hyperlipaemia PoM }(\mathrm{p}<0.05)\end{array}$ \\
\hline $\begin{array}{l}\text { Silva et al. } \\
(2005)^{(102)}\end{array}$ & $\begin{array}{l}52-76 \text { y }(62 \text { y) } \\
\text { n } 17\end{array}$ & $\begin{array}{l}\text { Cross } \\
\text { sectional }\end{array}$ & $\begin{array}{l}\text { Seque } \\
\text { ntial }\end{array}$ & $\begin{array}{l}\text { Breakfast: } \\
30 \mathrm{~g}(46 \%) \\
\text { Lunch: } \\
44 \mathrm{~g}(52 \%)\end{array}$ & $\begin{array}{l}\text { Breakfast (27 \%E SFA, } 12 \% \mathrm{E} \\
\text { MUFA, } 5 \% \text { E PUFA and } 2 \% \mathrm{E} \\
\text { Trans) } \\
\text { Lunch (27 \%E SFA, } 18 \% \mathrm{E} \\
\text { MUFA, } 5 \% \text { E PUFA and } 2 \% \mathrm{E} \\
\text { Trans) }\end{array}$ & $10 \mathrm{~h}$ & $\begin{array}{l}\text { TAG, and apo } \\
\text { B- } 48\end{array}$ & $\begin{array}{l}\uparrow \mathrm{TAG} \text { at } 210 \text { min after breakfast and } \\
60 \text { min after lunch } \\
\uparrow \text { Apo B- } 48 \text { at } 150 \text { min after breakfast } \\
\text { and } 60 \text { min after lunch }\end{array}$ \\
\hline $\begin{array}{l}\text { Alssema et al. } \\
(2008)^{(96)}\end{array}$ & 60.1 y n 76 & $\begin{array}{l}\text { Cross } \\
\text { sectional }^{*}\end{array}$ & $\begin{array}{l}\text { Seque } \\
\text { ntial }\end{array}$ & $\begin{array}{l}\text { Both breakfast } \\
\text { and lunch } \\
\text { compositions: } \\
\text { Fat rich meal: } \\
50 \mathrm{~g} \text { fat, }\end{array}$ & No information & $8 \mathrm{~h}$ & $\begin{array}{l}\text { TAG, HDL-C } \\
\text { and CETP }\end{array}$ & $\begin{array}{l}\uparrow \mathrm{TAG} \text { at } 8 \mathrm{~h}(\mathrm{p}<0.05), \downarrow \text { HDL-C at } 8 \mathrm{~h} \\
(\mathrm{p}<0.05) \text { in fat rich meal } \\
\uparrow \mathrm{TAG} \text { at } 8 \mathrm{~h}(\mathrm{p}<0.05), \downarrow \text { HDL-C at } 8 \mathrm{~h} \\
\text { and } \uparrow C E T P \text { in } \mathrm{CHO} \text { rich meal } \\
(\mathrm{p}<0.05)\end{array}$ \\
\hline
\end{tabular}


$56 \mathrm{~g} \mathrm{CHO}$,

$28 \mathrm{~g}$ protein

\section{$\mathrm{CHO}$ rich}

meal:

$4 \mathrm{~g}$ fat,

$162 \mathrm{~g} \mathrm{CHO}$,

$22 \mathrm{~g}$ protein

Wassef et al.

$(2012)^{(103)}$

58 y (45-74 y)

n 19 obese PoM

Cross

sectional*

Robertson $e t$

$50-63$ y (56 y)

n 10

$(2002 a)^{(98)}$

Jackson et al.

$(2002 b)^{(97)}$
Single

${ }^{13} \mathrm{C}$-labeled breakfast $80 \mathrm{~g}$

fat $(68 \%)$

$0.017 \mathrm{~g}$

${ }^{13} \mathrm{C}$-triolein/g

fat

Seque Breakfast:

$41 \mathrm{~g}^{\dagger}$

Lunch:

$6 \mathrm{~g}$
Jackson etal.
$25 \%$ E SFA, $26 \%$ E MUFA,

$10 \% \mathrm{E}$ PUFA and $6 \% \mathrm{E}$ other

sources

\section{High SFA (g/100 g):}

$10 \mathrm{~g}$ n-6 PUFA, $0 \mathrm{~g}$ n-3 PUFA,

$40 \mathrm{~g}$ MUFA and $50 \mathrm{~g}$ SFA

High MUFA (g/100 g):

$11 \mathrm{~g}$ n-6 PUFA, $0 \mathrm{~g}$ n-3 PUFA,

$72 \mathrm{~g}$ MUFA and $17 \mathrm{~g}$ SFA

High n-6 PUFA (g/100 g): $74 \mathrm{~g}$ n-6PUFA, 0 g n-3 PUFA, $15 \mathrm{~g}$ MUFA and $11 \mathrm{~g}$ SFA

High n-3/n-6 PUFA (g/100 g): $39 \mathrm{~g} \mathrm{n}-6$ PUFA, $22 \mathrm{~g} \mathrm{n}-3$ PUFA, $22 \mathrm{~g}$ MUFA and $19 \mathrm{~g}$ SFA

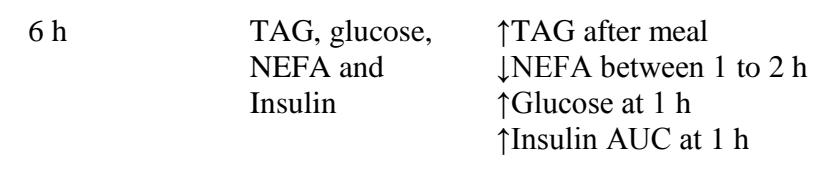

Glucose,

NEFA and

insulin

TAG and

apo B-48

TAG, apo B-48, and in three

TAG-rich

lipoprotein

subfractions

$\uparrow$ Glucose at $1 \mathrm{~h}$

$\uparrow$ Insulin AUC at $1 \mathrm{~h}$

$(\mathrm{p}<0.006)$

high-CHO meal

$<\mathrm{n}-3$ PUFA < MUFA $(\mathrm{p} \leq 0.009)$

MUFA meals $(p<0.04)$
High insulin response: SFA > n-6

PUFA $>$ n-3 PUFA $>$ MUFA

Glucose: No significant effect

$\uparrow N E F A$ at $5 \mathrm{~h}$ following high SFA

breakfast and $30 \mathrm{~min}$ after low-fat

$\downarrow$ insulin sensitivity: SFA < n-6 PUFA

$\uparrow$ apo B-48 in MUFA than SFA, $n-6$

PUFA and n-3/n-6 PUFA meals

apo B-48 IAUC in the $\mathrm{S}_{\mathrm{f}} 60-400$ fraction greater than in the $S_{f}>400$

fraction for the SFA, n-6 PUFA and

$\uparrow$ apo B-48 IAUC in the $\mathrm{Sf}>400$

fraction in MUFA than SFA, n- 6

PUFA and n-3/n-6 PUFA meals

$(\mathrm{p}<0.02)$

\begin{tabular}{lll}
\hline Postprandial lipaemia and vascular function \\
\hline Siepi et al. & 57 y n 10 & Cross \\
$(2002)^{(101)}$ & & sectiona
\end{tabular}

Single $65 \mathrm{~g}$

PUFA: SFA 0.06

$6 \mathrm{~h}$

TAG and GSH

$\uparrow$ TAG at 4 and $6 \mathrm{~h}(\mathrm{p}<0.05)$

$\downarrow \mathrm{GSH}$ at $2 \mathrm{~h}(\mathrm{p}<0.05)$

Brachial FMD

$\downarrow$ FMD at $2 \mathrm{~h}(\mathrm{p}<0.05)$

* No comparator group. 
$\dagger$ Values given per $100 \mathrm{~g}$ of test oil of which $41 \mathrm{~g}$ was included in the breakfast.

Arrows refer to the direction of change over time relative to baseline (fasting), unless otherwise stated.

Abbreviations: AUC; area under the curve, CETP; cholesteryl ester transfer protein, CHO; carbohydrate, E; energy, FMD; flow-mediated dilatation, GSH; glutathione, HDL-C; high density lipoprotein cholesterol, IAUC; incremental area under the curve, LDL; low density lipoprotein, Lp (a);

lipoprotein (a), MaxC; maximum concentration, MUFA; monounsaturated fat, NEFA; non-esterified fatty acid, PoM; postmenopausal women, PrM; premenopausal women, PUFA; polyunsaturated fat, RE; Retinyl esters, SFA; saturated fat, TAG; triacylglycerol, TC; total cholesterol. 


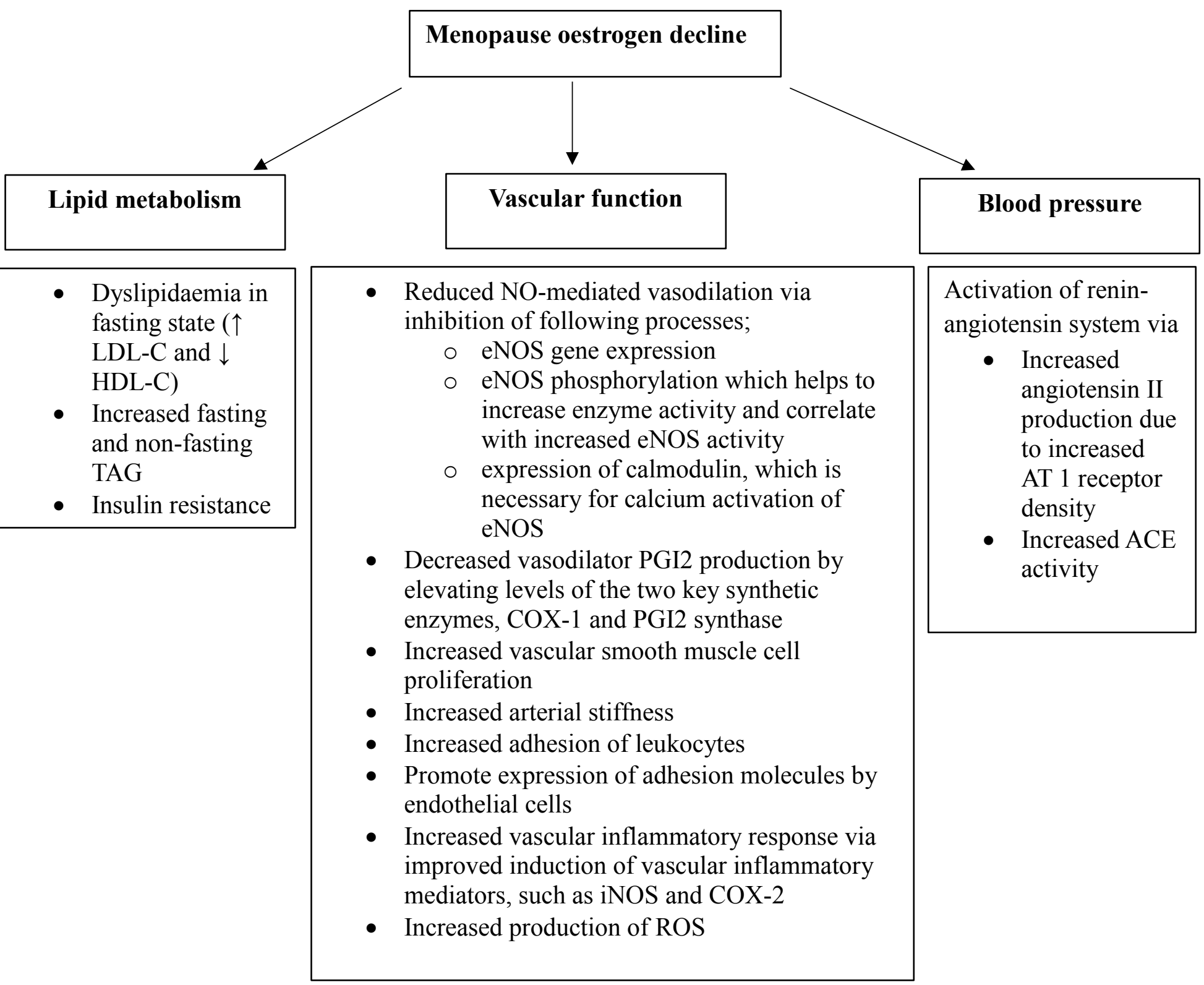

Figure 1: Consequences of the decline in oestrogen during the menopause on the lipid profile, endothelial function and blood pressure. Adapted from Davis et al. ${ }^{(106)}$ Abbreviations: ACE; angiotensin converting enzyme, AT-1; angiotensin I receptor, COX; cyclooxygenase, eNOS; endothelial nitric oxide synthase, HDL-C; high density lipoprotein cholesterol, iNOS; inducible NO synthase, LDL-C; low density lipoprotein cholesterol, NO; nitric oxide, PGI; prostaglandin, ROS; reactive oxygen species, TAG; Triacylglycerol 


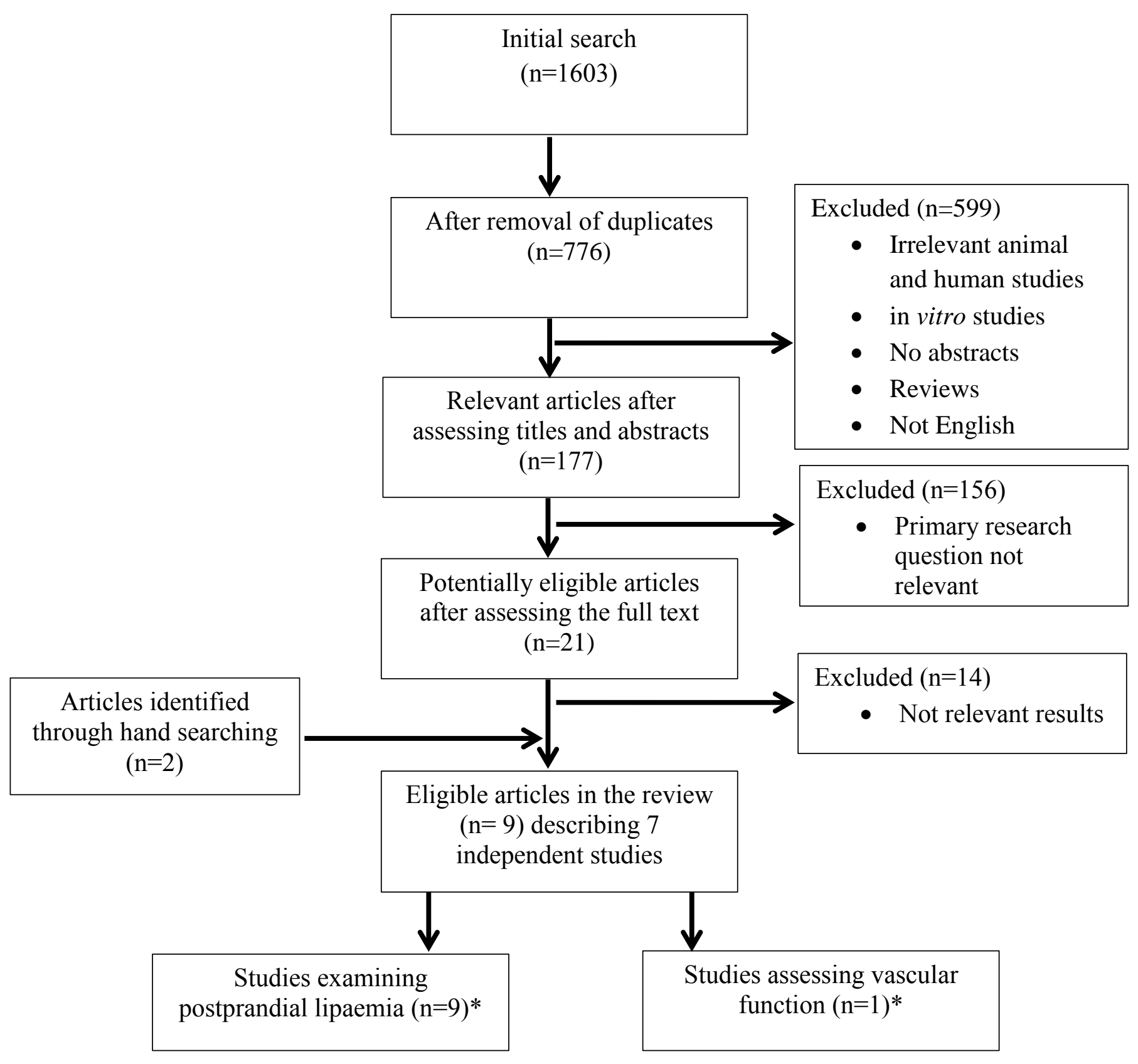

\section{Figure 2: Flow of information through the different phases of the review}

* Of the studies included in the review, one publication reported both postprandial lipaemia and vascular function. 
Supplementary Table 1 Acute test meal studies investigating the impact of menopausal status on the variability of the postprandial lipaemic responses

* No comparator group.

$\uparrow$ Values given per $100 \mathrm{~g}$ of test oil of which $41 \mathrm{~g}$ was included in the breakfast.

\begin{tabular}{|c|c|c|c|c|c|c|c|c|}
\hline Reference & $\begin{array}{l}\text { Subject group, } \\
\text { age (mean) and n }\end{array}$ & $\begin{array}{l}\text { Study } \\
\text { design }\end{array}$ & $\begin{array}{l}\text { Meal } \\
\text { type }\end{array}$ & $\begin{array}{l}\text { Amount of } \\
\text { fat (\% meal } \\
\text { fat if } \\
\text { available) }\end{array}$ & Fatty acid composition & $\begin{array}{l}\text { Time of } \\
\text { postprandial } \\
\text { data }\end{array}$ & $\begin{array}{l}\text { Postprandial } \\
\text { measurements }\end{array}$ & Significant outcomes \\
\hline $\begin{array}{l}\text { van Beek et } \\
\text { al. }(1999)^{(18)}\end{array}$ & $\begin{array}{l}\text { 47-52 y }(50 \text { y) } \\
\text { n } 23 \text { PoM women } \\
\text { and } 47-52 \text { y }(49 \text { y) } \\
\text { n } 21 \text { PrM women }\end{array}$ & $\begin{array}{l}\text { Case } \\
\text { control }\end{array}$ & Single & $50 \mathrm{~g}(40 \%)$ & PUFA: SFA 0.06 & $12 \mathrm{~h}$ & $\begin{array}{l}\text { TAG and } \\
\text { Vitamin } \\
\text { A/retinyl } \\
\text { palmitate }\end{array}$ & $\begin{array}{l}\uparrow \text { TAG AUC at } 0-8 \mathrm{~h}(\mathrm{p}=0.024) \\
\uparrow \mathrm{TAG} \triangle \mathrm{AUC}(\mathrm{p}=0.020) \text { in PoM } \\
\text { compared to PrM at } 0-8 \mathrm{~h} \\
\uparrow \text { Vitamin A AUC ( }=0.001) \text { in PoM } \\
\text { compared to PrM at } 0-8 \mathrm{~h}\end{array}$ \\
\hline $\begin{array}{l}\text { Masding et al. } \\
(2006)^{(20)}\end{array}$ & $\begin{array}{l}34-56 \text { y }(42 \text { y) n } 8 \\
\text { PrM and } 46-68 \text { y } \\
\text { (58 y) n } 8 \text { PoM } \\
\text { healthy } \\
32-54 \text { y ( } 39 \text { y) n } 8 \\
\text { PrM and } 53-70 \text { y } \\
\text { (61y) n } 8 \text { PoM } \\
\text { type } 2 \text { diabetic }\end{array}$ & $\begin{array}{l}\text { Case and } \\
\text { control }\end{array}$ & Single & $45 \mathrm{~g}$ & No information & $6 \mathrm{~h}$ & $\begin{array}{l}\text { TAG, NEFA, } \\
\text { Glucose, and } \\
{ }^{13} \text { C-palmitic } \\
\text { acid }\end{array}$ & $\begin{array}{l}\uparrow T A G \text { AUC in healthy PoM than PrM } \\
(\mathrm{p}<0.05) \\
\uparrow^{13} \mathrm{C}-\text { palmitic acid in healthy PoM } \\
\text { than PrM }(\mathrm{p}<0.01)\end{array}$ \\
\hline $\begin{array}{l}\text { Schoppen } e t \\
\text { al. }(2010)^{(19)}\end{array}$ & $\begin{array}{l}18-36 \text { y }(20.9 \text { y) } \\
\text { n } 20 \text { PrM and } \\
51-59 \text { y }(55.7 \text { y) } \\
\text { n } 18 \text { PoM }\end{array}$ & $\begin{array}{l}\text { Case and } \\
\text { control }\end{array}$ & Single & $\begin{array}{l}\text { Breakfast: } \\
75.3 \mathrm{~g} \\
(62.3 \%)\end{array}$ & $\begin{array}{l}11.8 \% \text { E SFA, } 39.7 \% \text { E MUFA } \\
\text { and } 6.6 \% \text { E PUFA }\end{array}$ & $7 \mathrm{~h}$ & TAG and TC & $\begin{array}{l}\uparrow \text { TAG and TC in PoM than PrM } \\
(\mathrm{p}<0.0001) \\
\text { Peak TAG at } 240 \mathrm{~min} \text { in PoM and } 120 \\
\text { min PrM }(\mathrm{p}<0.0001)\end{array}$ \\
\hline 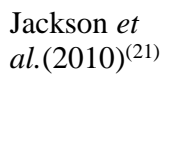 & $\begin{array}{l}42 \text { y n } 37 \text { PrM and } \\
60 \text { y n } 61 \text { PoM }\end{array}$ & $\begin{array}{l}\text { Case and } \\
\text { control }\end{array}$ & $\begin{array}{l}\text { Seque } \\
\text { ntial }\end{array}$ & $\begin{array}{l}\text { Breakfast: } \\
51 \mathrm{~g} \\
\text { Lunch: } \\
31 \mathrm{~g}\end{array}$ & $\begin{array}{l}29 \mathrm{~g} \mathrm{SFA} \text { at breakfast and } 14 \mathrm{~g} \\
\text { SFA at lunch }\end{array}$ & $8 \mathrm{~h}$ & TAG & $\begin{array}{l}\uparrow \text { TAG IAUC }(\mathrm{p}=0.002), \text { MaxC } \\
(\mathrm{p}=0.037) \text { and time to reach MaxC } \\
(\mathrm{p}=0.009) \text { in PoM than PrM }\end{array}$ \\
\hline
\end{tabular}

Arrows refer to the direction of change over time compared with premenopausal women.

Abbreviations: AUC; area under the curve, HDL; high density lipoprotein, IAUC; incremental area under the curve, LDL; low density lipoprotein, Lp (a); lipoprotein (a), MaxC; maximum concentration, MUFA; monounsaturated fat, NEFA; non-esterified fatty acid, PoM; postmenopausal women, PrM; premenopausal women, PUFA; polyunsaturated fat, SFA; saturated fat, TAG; triacylglycerol, TC; total cholesterol. 


\section{Reference}

1. Schwenke DC (1998) Antioxidants and atherogenesis. J Nutr Biochem 9(8): 424-445

2. World Health Organization (2017) Top 10 causes of death worldwide. http://www.who.int/mediacentre/factsheets/fs310/en/ (accessed on March 2017).

3. British Heart Foundation (2014) Cardiovascular Disease Statistics 2014. London: BHF.

4. World Health Organization (2008) The global burden of disease: 2004 update. Geneva: WHO.

5. Libby P, Ridker PM, Maseri A (2002) Inflammation and atherosclerosis. Circulation 105, 1135 1143.

6. Smith SC (2007) Multiple risk factors for cardiovascular disease and diabetes mellitus. Am J Med 120, S3-S11.

7. Celermajer DS, Sorensen KE, Spiegelhalter DJ et al. (1994) Aging is associated with endothelial dysfunction in healthy men years before the age-related decline in women. J Am Coll Cardiol 24, 471-476.

8. Pokoradi AJ, Iversen L, Hannaford PC (2011) Factors associated with age of onset and type of menopause in a cohort of UK women. Am J Obstet Gynecol 34, e31-34.

9. Wenger NK, Speroff L, Packard B (1993) Cardiovascular health and disease in women. N Engl J Med 329, 247-256.

10. Van der Schouw Y, van der Graaf Y, Steyerberg E et al. (1996) Age at menopause as a risk factor for cardiovascular mortality. Lancet 347, 714-718.

11. D Kolovou G, P Mikhailidis D, G Nordestgaard B et al. (2011) Definition of postprandial lipaemia. Curr Vasc Pharmacol 9, 292-301.

12. Bjorkegren J, Packard C, Hamsten A et al. (1996) Accumulation of large very low density lipoprotein in plasma during intravenous infusion of a chylomicron-like triglyceride emulsion reflects competition for a common lipolytic pathway. J Lipid Res 37, 76-86.

13. Jackson KG, Poppitt SD \& Minihane AM (2012) Postprandial lipemia and cardiovascular disease risk: Interrelationships between dietary, physiological and genetic determinants. Atherosclerosis 220, 22-33.

14. Chapman MJ, Le Goff W, Guerin M et al. (2010) Cholesteryl ester transfer protein: at the heart of the action of lipid-modulating therapy with statins, fibrates, niacin, and cholesteryl ester transfer protein inhibitors. Eur Heart J 31, 149-164.

15. Bansal S, Buring JE, Rifai N et al. (2007) Fasting compared with nonfasting triglycerides and risk of cardiovascular events in women. JAMA 298 (3): 309-316.

16. Langsted A, Freiberg J, Tybjaerg-Hansen A et al. (2011) Nonfasting cholesterol and triglycerides and association with risk of myocardial infarction and total mortality: The Copenhagen City Heart Study with 31 years of follow-up. J Intern Med 270, 65-75. 
17. Lindman AS, Veierød M, Tverdal A et al. (2010) Nonfasting triglycerides and risk of cardiovascular death in men and women from the Norwegian Counties Study. Eur J Epidemiol 25, 789-798.

18. van Beek AP, de Ruijter-Heijstek FC, Erkelens DW et al. (1999) Menopause is associated with reduced protection from postprandial lipemia. Arterioscler Thromb Vasc Biol 19, 2737-2741.

19. Schoppen S, Perez-Granados AM, Navas-Carretero S et al. (2010) Postprandial lipaemia and endothelial adhesion molecules in pre- and postmenopausal Spanish women. Nutr Hosp 25, 256261.

20. Masding MG, Stears AJ, Burdge GC et al. (2006) The benefits of oestrogens on postprandial lipid metabolism are lost in post-menopausal women with Type 2 diabetes. Diabet Med 23, 768774.

21. Jackson KG, Abraham EC, Smith AM et al. (2010) Impact of age and menopausal status on the postprandial triacylglycerol response in healthy women. Atherosclerosis 208, 246-252.

22. Cohn JS, McNamara J, Cohn S et al. (1988) Postprandial plasma lipoprotein changes in human subjects of different ages. J Lipid Res 29, 469-479.

23. Jackson KG, Clarke DT, Murray P et al. (2010) Introduction to the DISRUPT postprandial database: subjects, studies and methodologies. Genes Nutr 5, 39-48.

24. Koutsari C, Zagana A, Tzoras I et al. (2004) Gender influence on plasma triacylglycerol response to meals with different monounsaturated and saturated fatty acid content. Eur J Clin Nutr 58, 495-502.

25. Tentor J, Harada LM, Nakamura RT et al. (2006) Sex-dependent variables in the modulation of postalimentary lipemia. Nutr J 22, 9-15.

26. Burdge GC, Powell J \& Calder PC (2006) Lack of effect of meal fatty acid composition on postprandial lipid, glucose and insulin responses in men and women aged 50-65 years consuming their habitual diets. Br J Nutr 96, 489-500.

27. Bass KM, Newschaffer CJ, Klag MJ et al. (1993) Plasma lipoprotein levels as predictors of cardiovascular death in women. Arch Intern Med 153, 2209-2216.

38. Kannel WB (1987) Metabolic risk factors for coronary heart disease in women: perspective from the Framingham Study. Am Heart J 114(2): 413-419.

29. Nordestgaard BG, Benn M, Schnohr P et al. (2007) Nonfasting triglycerides and risk of myocardial infarction, ischemic heart disease, and death in men and women. JAMA 298, 299-308. 30. Burger HG, Dudley EC, Robertson DM et al. (2002) Hormonal changes in the menopause transition. Recent Prog Horm Res 57, 257-276.

31. Žegura B, Gužič-Salobir B (2009) Hormone replacement therapy in postmenopause and cardiovascular diseases: facts and dilemmas. Zdrav Vestn $\mathbf{7 8 .}$ 
32. Vehkavaara S, Silveira A, Hakala-Ala-Pietilä T et al. (2001) Effects of oral and transdermal estrogen replacement therapy on markers of coagulation, fibrinolysis, inflammation and serum lipids and lipoproteins in postmenopausal women. Thromb Haemost 85, 619-625.

33. Windler E, Kovanen PT, Chao Y-S et al. (1980) The estradiol-stimulated lipoprotein receptor of rat liver-A binding site that membrane mediates the uptake of rat lipoproteins containing apoproteins B and E. J. Biol. Chem 255, 10464-10471.

34. Gordon DJ, Probstfield JL, Garrison RJ et al. (1989) High-density lipoprotein cholesterol and cardiovascular disease - 4 prospective American studies. Circulation 79, 8-15.

35. Bessesen DH, Cox-York KA, Hernandez TL et al. (2015) Postprandial triglycerides and adipose tissue storage of dietary fatty acids: Impact of menopause and estradiol. Obesity 23, 145-153.

36. Westerveld HT, Kock L, Van Rijn H et al. (1995) 17 beta-Estradiol improves postprandial lipid metabolism in postmenopausal women. J Clin Endocrinol Metab 80, 249-253.

37. Huang Y, Wang S, Cai X et al. (2013) Prehypertension and incidence of cardiovascular disease: a meta-analysis. BMC Med 11, 177.

38. Ettehad D, Emdin CA, Kiran A et al. (2016) Blood pressure lowering for prevention of cardiovascular disease and death: a systematic review and meta-analysis. Lancet 387, 957-967. 39. Vlachopoulos C, Aznaouridis K, Stefanadis C (2010) Prediction of cardiovascular events and all-cause mortality with arterial stiffness: a systematic review and meta-analysis. J Am Coll Cardiol 55, 1318-1327.

40. Ras RT, Streppel MT, Draijer R et al. (2013) Flow-mediated dilation and cardiovascular risk prediction: a systematic review with meta-analysis. Int J Cardiol 168, 344-351.

41. Matsuzawa Y, Kwon TG, Lennon RJ et al. (2015) Prognostic value of flow-mediated vasodilation in brachial artery and fingertip artery for cardiovascular events: A systematic review and meta-analysis. J Am Heart Assoc 4, e002270.

42. Yao S-K, Ober JC, Krishnaswami A et al. (1992) Endogenous nitric oxide protects against platelet aggregation and cyclic flow variations in stenosed and endothelium-injured arteries.

Circulation 86, 1302-1309.

43. Cohen RA (1995) The role of nitric oxide and other endothelium-derived vasoactive substances in vascular disease. Prog Cardiovasc Dis 38, 105-128.

44. Verma S, Anderson TJ (2002) Fundamentals of endothelial function for the clinical cardiologist. Circulation 105, 546-549.

45. Widlansky ME, Gokce N, Keaney JF et al. (2003) The clinical implications of endothelial dysfunction. J Am Coll Cardiol 42, 1149-1160.

46. Rossi R, Nuzzo A, Origliani G et al. (2008) Prognostic role of flow-mediated dilation and cardiac risk factors in post-menopausal women. J Am Coll Cardiol 51, 997-1002. 
47. Taddei S, Virdis A, Ghiadoni L et al. (1996) Menopause is associated with endothelial dysfunction in women. Hypertension 28, 576-582.

48. Fichtlscherer S, Rosenberger G, Walter DH et al. (2000) Elevated C-reactive protein levels and impaired endothelial vasoreactivity in patients with coronary artery disease. Circulation 102, 10001006.

49. Moens AL, Goovaerts I, Claeys MJ et al. (2005) Flow-Mediated VasodilationA Diagnostic Instrument, or an Experimental Tool? Chest 127, 2254-2263.

50. Inaba Y, Chen JA, Bergmann SR (2010) Prediction of future cardiovascular outcomes by flowmediated vasodilatation of brachial artery: a meta-analysis. The international journal of cardiovascular imaging 26, 631-640.

51. Schächinger V, Britten MB, Zeiher AM (2000) Prognostic impact of coronary vasodilator dysfunction on adverse long-term outcome of coronary heart disease. Circulation 101, 1899-1906. 52. Moreau KL, Hildreth KL, Meditz AL et al. (2012) Endothelial function is impaired across the stages of the menopause transition in healthy women. J Clin Endocrinol Metab 97, 4692-4700. 53. Majmudar N, Robson S, Ford G (2000) Effects of the menopause, gender, and estrogen replacement therapy on vascular nitric oxide activity. J Clin Endocrinol Metab 85, 1577-1583. 54. Gilligan DM, Badar DM, Panza JA et al. (1994) Acute vascular effects of estrogen in postmenopausal women. Circulation 90, 786-791.

55. Brodsky SV, Gealekman O, Chen J et al. (2004) Prevention and reversal of premature endothelial cell senescence and vasculopathy in obesity-induced diabetes by ebselen. Circ Res 94, 377-384.

56. Ospina JA, Duckles SP, Krause DN (2003) 17 $\beta$-Estradiol decreases vascular tone in cerebral arteries by shifting COX-dependent vasoconstriction to vasodilation. Am J Physiol Heart Circ Physiol 285, H241-H250.

57. Ospina JA, Krause DN, Duckles SP (2002) 17ß-Estradiol increases rat cerebrovascular prostacyclin synthesis by elevating cyclooxygenase-1 and prostacyclin synthase. Stroke 33, 600605.

58. Manson JE, Aragaki AK, Rossouw JE et al. (2017) Menopausal Hormone Therapy and Longterm All-Cause and Cause-Specific Mortality: The Women's Health Initiative Randomized Trials. JAMA 318, 927-938.

59. Hsia J, Langer RD, Manson JE et al. (2006) Conjugated equine estrogens and coronary heart disease: The Women's Health Initiative. Arch Intern Med 166, 357-365.

60. Marjoribanks J, Farquhar C, Roberts H et al. (2017) Long-term hormone therapy for perimenopausal and postmenopausal women. Cochrane Libr. 
61. Žegura B, Gužic-Salobir B, Šebeštjen M et al. (2006) The effect of various menopausal hormone therapies on markers of inflammation, coagulation, fibrinolysis, lipids, and lipoproteins in healthy postmenopausal women. Menopause 13, 643-650.

62. Knopp RH, Zhu X, Bonet B (1994) Effects of estrogens on lipoprotein metabolism and cardiovascular disease in women. Atherosclerosis 110, S83-S91.

63. Vigen C, Hodis H, Chandler W et al. (2007) Postmenopausal oral estrogen therapy affects hemostatic factors, but does not account for reduction in the progression of subclinical atherosclerosis. Thromb Haemost 5, 1201-1208.

64. Wassertheil-Smoller S, Anderson G, Psaty BM et al. (2000) Hypertension and its treatment in postmenopausal women. Hypertension 36, 780-789.

65. Nash D, Magder L, Lustberg M et al. (2003) Blood lead, blood pressure, and hypertension in perimenopausal and postmenopausal women. JAMA 289, 1523-1532.

66. Abramson BL, Melvin RG (2014) Cardiovascular risk in women: focus on hypertension. Can J Cardiol 30, 553-559.

67. Donoghue M, Hsieh F, Baronas E et al. (2000) A novel angiotensin-converting enzyme-related carboxypeptidase (ACE2) converts angiotensin I to angiotensin 1-9. Circ Res 87, e1-e9.

68. Leung PS (2004) The peptide hormone angiotensin II: its new functions in tissues and organs. Curr Protein Pept Sci 5, 267-273.

69. Bell C (1973) Oestrogen-induced sensitization of the uterine artery of the guinea-pig to acetylcholine. Br J Pharmacol 49, 595-601.

70. Bell C, Coffey C (1982) Factors influencing oestrogen-induced sensitization to acetylcholine of guinea-pig uterine artery. J Reprod Fertil 66, 133-137.

71. Williams JK, Adams MR, Herrington DM et al. (1992) Short-term administration of estrogen and vascular responce of atherosclerotic coronary arteries. J Am Coll Cardiol 20, 452-457.

72. Hinojosa-Laborde C, Craig T, Zheng W et al. (2004) Ovariectomy augments hypertension in aging female Dahl salt-sensitive rats. Hypertension 44, 405-409.

73. Nickenig G, Bäumer AT, Grohè C et al. (1998) Estrogen modulates AT1 receptor gene expression in vitro and in vivo. Circulation 97, 2197-2201.

74. Nogawa N, Sumino H, Ichikawa S et al. (2001) Effect of long-term hormone replacement therapy on angiotensin-converting enzyme activity and bradykinin in postmenopausal women with essential hypertension and normotensive postmenopausal women. Menopause 8, 210-215. 75. Schunkert H, Danser AJ, Hense H-W et al. (1997) Effects of estrogen replacement therapy on the renin-angiotensin system in postmenopausal women. Circulation 95, 39-45. 
76. Ginnan R, Guikema BJ, Halligan KE et al. (2008) Regulation of smooth muscle by inducible nitric oxide synthase and NADPH oxidase in vascular proliferative diseases. Free Radic Biol Med 44, 1232-1245.

77. Ono H, Minatoguchi S, Watanabe K et al. (2008) Candesartan decreases carotid intima-media thickness by enhancing nitric oxide and decreasing oxidative stress in patients with hypertension. Hypertens Res 31, 271-279.

78. Wassmann S, Wassmann K, Nickenig G (2004) Modulation of oxidant and antioxidant enzyme expression and function in vascular cells. Hypertension 44, 381-386.

79. Fischer M, Baessler A, Schunkert H (2002) Renin angiotensin system and gender differences in the cardiovascular system. Cardiovasc Res 53, 672-677.

80. Yusuf S, Hawken S, Ônpuu S et al. (2004) Effect of potentially modifiable risk factors associated with myocardial infarction in 52 countries (the INTERHEART study): case-control study. Lancet 364, 937-952.

81. FAO (2008) Fats and fatty acids in Human Nutrition. Joint FAO/WHO expert consultation Food and Agriculture Organization of the United Nations: Rome

82. Hooper L, Summerbell CD, Thompson R et al. (2012) Reduced or modified dietary fat for preventing cardiovascular disease. Cochrane Libr.

83. Mozaffarian D, Micha R, Wallace S (2010) Effects on coronary heart disease of increasing polyunsaturated fat in place of saturated fat: a systematic review and meta-analysis of randomized controlled trials. PLoS Med 23;7(3): e1000252.

84. Monfort-Pires M, Delgado-Lista J, Gomez-Delgado F et al. (2016) Impact of the Content of Fatty Acids of Oral Fat Tolerance Tests on Postprandial Triglyceridemia: Systematic Review and Meta-Analysis. Nutrients 8, 580.

85. West SG (2001) Effect of diet on vascular reactivity: an emerging marker for vascular risk. Curr Atheroscler Rep 3, 446-455.

86. Ong PJ, Dean TS, Hayward CS et al. (1999) Effect of fat and carbohydrate consumption on endothelial function. Lancet 354, 2134.

87. Plotnick GD, Corretti MC, Vogel RA (1997) Effect of Antioxidant Vitamins on the Transient Impairment of Endothelium - Dependent Brachial Artery Vasoactivity Following a Single High-Fat Meal. JAMA 278, 1682-1686.

88. Vogel RA, Corretti MC, Plotnick GD (1997) Effect of a single high-fat meal on endothelial function in healthy subjects. Am J Cardiol 79, 350-354.

89. Vogel RA, Corretti MC, Plotnick GD (2000) The postprandial effect of components of the Mediterranean diet on endothelial function. J Am Coll Cardiol 36, 1455-1460. 
90. Pacher P, Beckman JS, Liaudet L (2007) Nitric oxide and peroxynitrite in health and disease. Physiol Rev 87, 315-424.

91. Förstermann U (2010) Nitric oxide and oxidative stress in vascular disease. Pflugers Arch 459, 923-939.

92. Margioris AN (2009) Fatty acids and postprandial inflammation. Curr Opin Clin Nutr Metab Care 12, 129-137.

93. Rubin D, Claas S, Pfeuffer M et al. (2008) s-ICAM-1 and s-VCAM-1 in healthy men are strongly associated with traits of the metabolic syndrome, becoming evident in the postprandial response to a lipid-rich meal. Lipids Health Dis 7, 32.

94. Hall WL (2009) Dietary saturated and unsaturated fats as determinants of blood pressure and vascular function. Nutr Res Rev 22, 18-38.

95. Vafeiadou K, Weech M, Sharma V et al. (2012) A review of the evidence for the effects of total dietary fat, saturated, monounsaturated and n- 6 polyunsaturated fatty acids on vascular function, endothelial progenitor cells and microparticles. Br J Nutr 107, 303-324.

96. Alssema M, Schindhelm RK, Dekker JM et al. (2008) Determinants of postprandial triglyceride and glucose responses after two consecutive fat-rich or carbohydrate-rich meals in normoglycemic women and in women with type 2 diabetes mellitus: The Hoorn Prandial Study. Metabolism 57, 1262-1269.

97. Jackson KG, Robertson MD, Fielding BA et al. (2002) Olive oil increases the number of triacylglycerol-rich chylomicron particles compared with other oils: an effect retained when a second standard meal is fed. Am J Clin Nutr 76, 942-949.

98. Jackson KG, Robertson MD, Fielding BA et al. (2002) Measurement of apolipoprotein B-48 in the Svedberg flotation rate $(\mathrm{Sf})>400, \mathrm{Sf} 60-400$ and Sf 20-60 lipoprotein fractions reveals novel findings with respect to the effects of dietary fatty acids on triacylglycerol-rich lipoproteins in postmenopausal women. Clin Sci 103, 227-237.

99. Pirro M, Lupattelli G, Siepi D et al. (2001) Postprandial lipemia and associated metabolic disturbances in healthy and hyperlipemic postmenopausal women. Metabolism 50, 330-334. 100. Robertson M, Jackson KG, Fielding B et al. (2002) Acute effects of meal fatty acid composition on insulin sensitivity in healthy post-menopausal women. Br J Nutr 88, 635-640. 101. Siepi D, Marchesi S, Lupattelli G et al. (2002) Postprandial endothelial impairment and reduced glutathione levels in postmenopausal women. Ann Nutr Metab 46, 32-37. 102. Silva K, Wright JW, Williams CM et al. (2005) Meal ingestion provokes entry of lipoproteins containing fat from the previous meal: possible metabolic implications. Eur J Clin Nutr 44, 377 383. 
103. Wassef H, Salem H, Bissonnette S et al. (2012) White adipose tissue apolipoprotein CI secretion in relation to delayed plasma clearance of dietary fat in humans. Arterioscler Thromb Vasc Biol 32, 2785-2793.

104. Westerveld HT, Meijer E, Erkelens DW et al. (1996) Postprandial reduction in high-density lipoprotein cholesterol concentrations in postmenopausal women: improvement by $17 \beta$-estradiol. Metabolism 45, 827-832.

105. Fielding BA, Callow J, Owen RM et al. (1996) Postprandial lipemia: the origin of an early peak studied by specific dietary fatty acid intake during sequential meals. Am J Clin Nutr 63, 36-41. 106. Davis SR, Lambrinoudaki I, Lumsden M et al. (2015) Menopause. Nat Rev Dis Primers 1, 15004. 